\title{
ETHICAL AND LEGAL ISSUES RELATED TO HEALTH ACCESS FOR Migrant POPULATIONS IN THE EURO-MediterRanean AREa
}

\author{
E Negro Calduch (enegro@isciii.es)1', A Diaz'1, M Diez¹, for the project "Impact of migration on HIV and TB Epidemiology in \\ the Mediterranean Area"2 \\ 1. HIV/AIDS Epidemiology Unit, Secretariat of the National Plan on AIDS, Directorate of Public Health and Border Health and \\ National Epidemiology Centre, Instituto de Salud Carlos III, Madrid, Spain \\ 2. http://www.sante.gov.ma/Departements/INH/WorkshopTBHIV/index.htm
}

The Institut National d'Hygiène (Morocco) and the Instituto de Salud Carlos III (Spain) are involved as a consortium in a project called "Impact of migration on HIV and TB Epidemiology in the Mediterranean Area", funded by the Sixth Framework Programme for research of the European Commission. The project started in May 2007 and is intended as a specific support action to promote international research cooperation in the Euro-Mediterranean area. In particular, its objective is to improve the capacity of the countries around the Mediterranean Basin for obtaining quality epidemiological information on human immunodeficiency virus (HIV) and tuberculosis (TB) among migrants, while taking into consideration ethical and legal issues related to health in migrant populations. To this end, the project proposed to hold two workshops to bring together all the relevant stakeholders: delegates of international and national non-governmental organisations (NGOs) concerned with the process, experts and health professionals, researchers, representatives of the United Nations Agencies and other decision makers.

The first workshop was dedicated to reviewing epidemiological and laboratory issues and was held in Rabat (Morocco) in November 2007. An account of the main issues covered at this workshop has been published [1].

France, Italy, Mauritania, Morocco, Portugal, Spain and Tunisia were represented at the second workshop, which took place in Madrid from 25 to 27 June 2008. This second workshop was intended to provide an overview on the ethical and legal issues related to health in migrant populations, contributing to the EuroMediterranean dialogue on the situation of migrants. In addition, it aimed at determining the specific requirements to be taken into consideration when trying to improving the epidemiologic surveillance of HIV and TB in migrant populations.

The workshop was organised around four main topics:

a) Migrants and health: ethical and legal issues;

b) Access of migrants to prevention and care for HIV and TB;

c) Stigma and discrimination;

d) The way forward: role of different stakeholders in improving health care and health information in migrants.

A summary of the discussions on those topics during the Madrid meeting are provided below.
Migrants and health: ethical and legal issues

The right to health, regardless of the legal status of individuals, is recognised widely in the different legislative frameworks, both at international and national level.

In the international context, the most important regulations on immigration and health matters are: the WHO Constitution (1946) [2], the Universal Declaration on Human Rights (1948) [3], the International Convention on the Protection of the Rights of All Migrant Workers and Members of Their Families (1990) [4], the International Labour Organization (ILO) Conventions 97 and 143 [5], the Declaration on the Human Rights of Individuals who are not Nationals of the Country in which they Live (1985) [6], the Convention relating to the Status of Refugees (1951) [7] and the Guiding Principles on Internal Displacement (1998) [8]. Those conventions have been ratified by most countries in the world, including those belonging to the European Union (EU) and the Mediterranean region. In addition, national legislation recognising the right to health as a fundamental human right exists in EuroMediterranean countries. Furthermore, the Council of Europe has recognised the right of everyone to attainable standards of physical and mental health and the right to receive health care in the event of sickness and pregnancy. Moreover, any legislation or practice that denies the provision of medical assistance to foreign nationals within Europe, even if they are undocumented, is contrary to the European Social Charter [9].

Given the legal framework, policy options that contravene the United Nations and European conventions should not be pursued in the Euro-Mediterranean area, and current legislation should be enforced and implemented. Nevertheless, it is unclear how immigrants, especially undocumented, receive health care in case of need in many countries of the area.

Access of migrants to prevention and care for HIV and TB

Early detection and treatment of HIV and TB in foreign-born individuals in the host country has proved to have an enormous potential public health benefit.

The rationale for treating people living with HIV/AIDS (PLWHA) with highly active anti-retroviral therapy (HAART) or TB patients with anti-TB drugs is based both on human rights and public health protection grounds. HAART decreases HIV-related morbidity 
and mortality, enabling infected people to remain socially and economically active, and reduces the infectivity of PLWHA, thus becoming an important prevention instrument for HIV transmission $[10,11]$. Likewise, treating TB patients, apart from the individual beneficial impact, is the most important TB control measure [12].

The provision of health services for TB and HIV patients is obviously subject to certain economic considerations. For this reason, cost-effectiveness analyses of HIV and TB treatment have been carried out in different settings, concluding that both interventions are cost-effective.

There are great variations in self-perceived health and utilisation of health services both among migrant populations coming from other countries and migrant groups from different parts of the same country. Thus, migrant populations are heterogeneous and should not be considered as one entity. In addition, undocumented migrants may be less likely to regularly attend health services for fear of legal actions against them. In this respect, some studies have shown that, contrary to many health professionals' and the general public's perception, migrants tend to utilise healthcare services less than nationals [13].

Access of migrants to health services might be particularly difficult in the event of incarceration. Some countries like Spain have shown that it is possible to implement prevention programmes for TB and HIV, including syringe exchange programmes, in prisons. Health policies should guarantee that prisoners and non-prisoners receive equal conditions regarding prevention and healthcare services provided, and that migrants have access to them on the same basis as nationals.

On the subject of HIV and TB screening, additional considerations must be taken into account, since affected individuals can be exposed to stigma and ostracism that might be compounded by compulsory health screening. Screening of migrants for TB and HIV is carried out in many countries, but the evidence base in support of this policy is weak. Compulsory screening is expensive in terms of both start-up and recurring costs and, once implemented, is difficult to halt. Resources allocated to compulsory screening might be more effectively directed into providing better health care and preventive services [14, 15].

NGOs operating in the Euro-Mediterranean area include among their activities free healthcare services for migrants such as screening, counselling, information on healthcare access and prevention services. The vulnerability of migrant populations has been stressed by these NGOs. Migrants need to be reached and constructively engaged into community activities, taking into account their social and cultural characteristics. It is necessary to remove all the obstacles that migrants face when it comes to accessing prevention and health care.

\section{Stigma and discrimination}

Migrant populations around the world are likely to experience stigma and discrimination, in particular illegal migrants.

In addition, there is evidence indicating a growing "feminisation" of the migration phenomenon. Many women are forced to migrate due to discrimination and lack of opportunities in their countries of origin and those who are in low-skilled jobs or working illegally, especially in unregulated sectors such as domestic employment, are at a greater risk to suffer from violence, poor working conditions, long working hours, sexual exploitation and poor reproductive health. In Spain, migrant women from low-income countries have the worst health indicators, according to the "First Report on Inequalities and Health in Andalusia" [16]. To tackle social and gender discrimination, a coherent and integrated approach through health and social policies should be implemented.

Discrimination and stigmatisation is one of the dramatic consequences PLWHA have to face and a major obstacle to prevention and care. Fear of discrimination and stigma causes people to avoid testing and prompts those infected with and affected by HIV/AIDS to remain silent, depriving them from essential treatment and social care. These problems are perhaps magnified by the existing taboos regarding sexuality, affecting more intensively women.

The way forward: role of different stakeholders in improving

health care and health information in migrants

The unprecedented scale of migration to Europe for reasons of protection, employment and family reunion poses many opportunities and challenges. This is an area of policy making which is moving fast and involves many different stakeholders at the international, national and local level. In that respect, NGOs play an important role in providing socio-sanitary assistance to populations with difficult access to healthcare and in the emergency and humanitarian reception of undocumented migrants.

Public administrations in the host country must find solutions to cope with growing migration and arising needs, adapting existing health systems to the new situation [17]. For this purpose, it is important to study the health status, health needs and healthcare service utilisation of migrant populations. Similarly, it is necessary to know health professionals' perceptions and needs regarding the provision of healthcare to these populations.

At the international level, the International Organization for Migration (IOM) is the leading inter-governmental organisation in the field of migration and is dedicated to promoting humane and orderly migration. It does so by providing services and advice to governments and migrants. IOM acts at a political and operative level, working to achieve consistent immigration policies, to reduce vulnerability and improve migrants' health.

At the local level, health professionals play a fundamental role in improving healthcare and health information for migrants. Apart from difficulties in healthcare access, some concerns related to healthcare provision have been reported, such as language and cultural barriers, administrative problems and difficult diagnosis, treatment and follow-up. Institutional support is needed to improve this situation. The role of cultural mediators is particularly important in order to facilitate the relationship between nationals and migrants and promote reciprocal knowledge.

Europe is witnessing increases in migrant-associated TB and HIV, and these are important public health challenges. Migration cannot be avoided as long as economic differences prevail between the industrialised and the poor countries. The strongest policy instruments should be used to tackle this truly global issue at the appropriate levels. An example of best practice that should be built on across the EU and the Mediterranean region would be the provision of HIV and TB healthcare and preventive services to 
migrants, documented or undocumented, on the same basis as to nationals of the host countries. Networking of people working on migrant issues and development of common definitions and procedures is necessary to improve knowledge on the subject.

The workshop was organised by the HIV/AIDS Epidemiology Unit of the Secretariat of the National Plan on AIDS/Instituto de Salud Carlos III, Madrid and funded by DG RESEARC of the European Commission. The speakers were: Rajae El Aouad (project coordinator National Institute of Hygiene, Morocco), Mercedes Diez (project co-researcher, HIV/ AIDS Epidemiology Unit of the Secretariat of the National Plan on AIDS/Institut de Salud Carlos III, Spain), Enrique Acin García (General Directorate of Health in Prisons, Spain), Josefina Alventosa (Asociación deJuristas del Sida (JURISIDA), Spain) Delphine Antoine (Institut de Veille Sanitaire, France), Henrique Barros (Coordenaça Delphine Antoine (Institut de Veille Sanitaire, France), Henrique Barros (Coordenação Nacional para a Infecção VIH/sida, Portugal), Eddy Beck (UNAIDS, Switzerland), Aziza Bennani (National programme for HIV, Morocco), Nadia Bezad (Pan African Organization Against Aids, Morocco), José Chamizo (Defensor del Pueblo, Andalucía, Spain), Almuden Echevarría (Cruz Roja Española, Spain), Amine Ezzahri (Ministry of Health, Morocco) Mariam Fadlou- Allah (Association de Lutte Contre le Sida, Morocco), Diego Gracia Guillén (Universidad Autónoma de Madrid, Spain), Jamila Lamani (Association de Lutte Contre le Sida, Morocco), Rogelio López-Vélez (Tropical Medicine \& Clinical Parasitology. Hospital Ramón y Cajal, Spain), Tona Lizana Alcazo (Catalonian Health Department), Claudia Natali (International Organization for Migration, Switzerland) Paola Pace (International Organization for Migration, Switzerland), Tullio Prestileo ANLAIDS, Italy), Anna Rodés Monegal (Tuberculosis Programme, Generalitat de Catalonia Spain), Elena Rodríguez (Universidad del País Vasco, Spain), Ali Sadiq (Department of immigration and border surveillance, Morocco), Ahmed Zekri (Mohammed V University Agdal, Morocco. More information available at: http://www.sante.gov.ma/Departements/ INH/WorkshopTBHIV/index.htm).

\section{Acknowledgements}

The authors gratefully acknowledge the contribution of all participants of the second workshop of the project "Impact of migration on HIV and TB Epidemiology in the Mediterranean Area" and the financial support of the European Commission through the VI Framework Programme for Research (FP6) of DG RESEARCH.

\section{References}

1. Cherkaoui Imad. First workshop report of the project "Impact of immigration on tuberculosis and HIV epidemiology in the Mediterranean area". 2008. Sixth Framework Programme. DG Research. European Commission.

2. World Health Assembly. Constitution of the World Health Organization. New York 1946. Available from: http://www.who.int/governance/eb/who_constitution en.pdf

3. General Assembly of the United Nations. The Universal Declaration of Human Rights. 1948. Available from: http://www.un.org/Overview/rights.html

4. General Assembly of the United Nations. The International Convention on the Protection of the Rights of All Migrant Workers and Members of Their Families. 1990. Available from: http://www.unhchr.ch/html/menu3/b/m mwctoc.htm

5. The International Labour Organization. Conventions $97 \& 143.1949 \& 1975$. Available from: http://www.ilo.org/ilolex/english/convdisp1.htm

6. General Assembly of the United Nations. Declaration on the Human Rights of Individuals Who are not Nationals of the Country in which they Live. Geneva: The Office of the High Commissioner for Human Rights; 1985. Available from: http://www.unhchr.ch/html/menu3/b/o_nonnat.htm

7. General Assembly of the United Nations. Convention relating to the Status of Refugees. Geneva: The Office of the High Commissioner for Human Rights; 1951. Available from: http://www.unhchr.ch/htmL/menu3/b/o_c_ref.htm

8. United Nations Human Rights Commission. Guiding Principles on Internal Displacement. Geneva: The Office of the High Commissioner for Human Rights; 1998. Available from: http://www.unhchr.ch/html/menu2/7/b/principles.htm

9. Paola Pace (editor). Migration and the Right to Health: A Review of European Community Law and Council of Europe Instruments. Geneva: Organization for Migration; 2007. International Migration Law no. 12.

10. Beck EJ, Mandalia S, Youle M, Brettle R, Fisher M, Gompels M, et al. Treatment outcome and cost-effectiveness of different highly active antiretroviral therapy regimens in the UK (1996-2002). Int J STD AIDS. 2008;19(5):297-304.

11. Badri M, Maartens G, Mandalia S, Bekker LG, Penrod JR, Platt RW, et al. Costeffectiveness of highly active antiretroviral therapy in South Africa. PLoS Med. 2006;3(1):e4.
12. Tupasi TE, Gupta R, Quelapio MI, Orillaza RB, Mira NR, Belen VA, et al. Cost and cost-effectiveness of DOTS-Plus: evidence from the Philippines. Int J Tubercul Lung Dis. 2004;8(11):Suppl 1:S223.

13. Platform for International Cooperation on Undocumented Migrants (PICUM). Report of PICUM International Conference on Access to Health Care for Undocumented Migrants in Europe: June 28-29, 2007. Brussels: PICUM; 2007 Sept. Available from: http://www.picum.org/HOMEPAGE/PICUM\%2OHealth\%20 Care\%2OCONFERENCE\%2OREPORT\%202007\%20-\%20ENGLISH.pdf

14. Coker RJ, Bell A, Pitman R, Hayward A, Watson J. Screening programmes for tuberculosis in new entrants across Europe. Int J Tuberc Lung Dis. 2004:8(8):1022-6.

15. Dasgupta K, Menzies D. Cost-effectiveness of tuberculosis control strategies among immigrants and refugees. Eur Respir J. 2005:25(6):1107-16.

16. Association for the defense of public health care in Andalusia. First report on health and Inequalities in Andalusia. April 2007. Available from: http:// www.fadsp.org/pdf/resumen_parcial_INDESAN.doc

17. Organization for Migration. Health Systems Response to migrants. Powerpoint presentation. Available from: http://www.iom.int/jahia/webdav/site/myjahiasite/ shared/shared/mainsite/activities/health/health_systems_response.pdf

This article was published on 11 December 2008.

Citation style for this article: Negro Calduch E, Diaz A, Diez M, for the project "Impact of migration on HIV and TB Epidemiology in the Mediterranean Area". Ethical and legal issues related to health access for migrant populations in the Euro-Mediterranean Area. Euro Surveill. 2008;13(50):pii=19061. Available online: http://www.eurosurveillance.org/ ViewArticle.aspx?ArticleId $=19061$ 